\title{
水中に微量に溶存する農薬の数種水棲生物による取り込み*
}

\author{
柘植茂晃**, 西村隆 信***, 風野 光****, 富沢長次郎**** \\ $* *, * * *$ 農林水産省農薬検査所 \\ $* * * *$ 農林水産省農業技術研究所 \\ (昭和 55 年 6 月 15 日受理)
}

\section{Uptake of Pesticides from Aquarium Tank Water by Aquatic Organisms*}

\author{
Shigeaki Tsuge, ${ }^{* *}$ Takanobu Nishimura, ${ }^{* * *}$ Hikaru KaZAno**** \\ and Chojiro TomizaWA**** \\ **,***Agricultural Chemicals Inspection Station, Kodaira, Tokyo 187, Japan \\ ****National Institute of Agricultural Sciences, 3-1-1 Kannondai, \\ Yatabe-machi, Tsukuba-gun, Ibaraki 305, Japan
}

\begin{abstract}
Aquatic organisms were kept in an aquarium tank containing $1 \mathrm{ppb}$ of chlorophenyl(U)- ${ }^{14} \mathrm{C}$-DDT, $1,2,3,4,10-14 \mathrm{C}$-aldrin, 2,4-dichlorophenyl-(U) - ${ }^{14} \mathrm{C}$-prothiophos $(\mathrm{O}-2,4$-dichlorophenyl $O$-ethyl $S$-propylphosphorodithioate), dimethyl-14 $C$-isothioate $[S-2-($ isopropylthio)ethyldimethylphosphorothiolothionate], naphthyl-1-14 $\mathrm{C}$-carbaryl, and $\mathrm{N}$-methyl $-{ }^{14} \mathrm{C}-\mathrm{XMC}$ (3,5-xylyl methylcarbamate), respectively, and uptake of these pesticides in guppy (Lebistes veticulatus Peters), red snail (Indoplanorbis exustus Deshays), mosquito larvae (Culex pipiens pallens molestus Foriskal) and Daphnia pulex deGeer was investigated. Uptake of DDT by mosquito larvae was the most rapid among the aquatic organisms tested, and the snail accumulated the least in this experiment. Aldrin was rapidly transformed to dieldrin in guppy, but was scarcely found at all in Daphnia. The uptake of prothiophos was high in Daphnia, differing from the lower uptake by other organisms which easily degraded this chemical compound. The uptake of isothioate, carbaryl and XMC was fairly low, and those three pesticides were metabolized rapidly by all organisms. The uptake and metabolism of pesticides were remarkably influenced by difference of aquatic organism species and chemical variety. It was also found that the uptake of pesticides in the present experiment was different from that in the model ecosystem study which involved a food chain system.
\end{abstract}

\section{緒言}

近年，多種類の化学物質が大量に生産されるに従って それらによる環境污染が社会問題となり，環境に打ける 残留性や水棲生物への蓄積性についての関心が高まって いる. とくに農薬については，その使用状況から，水系 の自然環境に与える影響は大きいと考えられるが，こう

* 本報告の概要は日本農薬学会第 2 回大会に挨いて 発表した.

** 現在：農林水産省農蚕園芸局果樹花き課 Present address: Fruit and Flower Division, Agricultural Production Division, Ministry of Agriculture, Forestry and Fisheries
した問題に対する研究は, 従来, 水棲生物に対する急性 毒性試験に関するものが多く, 農薬の種類や生物種の相 違による水棲生物への取り込みや蓄積性の有無について 行なわれた研究は必ずしも多くはない。

われわれはすすでに Metcalf らの考案したモデルェコ システム1を用いて, 生物濃縮に関する検討を重礼てき $た^{2 \sim 4)}$. この方法では, 陸系の生物や水系の微生物などを 経由した農薬の親化合物㧍よびその代謝物が, 呼吸, 体 表からの浸透, 食物連鎖などによって水棲生物に取り込 まれ,代謝分解され，あるいは蓄積される可能性の有無を 検討することはできるが, 系が複雑であるために, 生物 濃縮の主たる経路を明らかにすることはできなかった。

本報では, 系を単純化し, 微量の農薬が混入している 
水の中での, 種の異なる水棲生物による農薬の取り込み について検討した.

\section{実験材料および方法}

\section{1. 供試化合物}

本実験には，有機塩素殺虫荗の DDT，フルドリン， 有機リン殺虫剂のプロチオホス，イソチオェート，カー バメート殺虫片のカルバリル，XMC の計 6 種類の農薬 を使用した。 $p$-クロルフェニル-14C-(U)-標識- $p, p^{\prime}$ DDT（比放射能 $29.7 \mathrm{mCi} / \mathrm{mmol}$ ) と $1,2,3,4,10-{ }^{14} \mathrm{C}$ 標識ーアルドリン（比放射能 $40.0 \mathrm{mCi} / \mathrm{mmol}$ ）は英国 Amersham 社製を購入した。フェニル-14 $C-(\mathrm{U})-$ 標識プ ロチオホス $(O-2,4$-dichlorophenyl $O$-ethyl $S$-propylphosphorodithioate, 比放射能 $2.6 \mathrm{mCi} / \mathrm{mmol})$ は, ${ }^{14} \mathrm{C}$ (U)-sodium 2, 4-dichlorophenolate と $O$-ethyl $S$-propylphosphorochloridothionate から合成した ${ }^{5)}$. メチル $-{ }^{14} C$ 標識ーイソチオエート[S-2-(isopropylthio) ethyldimethylphosphorothiolothionate, 比放射能 $6.2 \mathrm{mCi} / \mathrm{mmole}$ ] は, 日本農薬株式会社から提供された。 1 -ナフチル $-1-{ }^{14} C-$ 標識-カルバリル（比放射能 $6.1 \mathrm{mCi} / \mathrm{mmole}$ ) と $N$-メチ ル ${ }^{14} C$ - 標識 - XMC (3,5-dimethylphenyl- $N$-methylcarbamate, 比放射能 $2.9 \mathrm{mCi} / \mathrm{mmole})$ は前報に打いて用 いたものと同じである2,3).

標識農薬は, いずれも使用直前に薄層クロマトグラフ ィー $(t l c$, シリカゲル GF-254, 厚さ $0.5 \mathrm{~mm}$ )により 精製して実験に供した。 $t l c$ に用いた展開溶媒と標品の $R f$ 值は次のとおりである.

DDT $(R f$ 0.55) : $n$-ヘキサンーエチルエーテル (100：

2)

アルドリン $(R f$ 0.81) : $n$-ヘキサンーエチルエーテル

(1:1)

プロチオホス $(R f$ 0.50): $n$-ヘキサンーエチルエーテ ル $(9: 1)$

イソチオエート $(R f 0.80): n$-ヘキサンーアセトン (8:2)

カルバリル $(R f$ 0.61) : エチルエーテルーn-ヘキサン $(4: 1)$

$\mathrm{XMC}(R f 0.53):$ エチルエーテルーnーヘキサン $(3: 1)$

放射化学的純度は $t l c$-オートラジオグラフィーにより いずれも $99 \%$ 以上であることを確認した.

\section{2. 想定代謝物}

$\mathrm{DDD}, \mathrm{DDE}$ ディルドリンおよび1-ナフトールは和光 純薬製を用いた. 5ーヒドロキシカルバリルは Dorough \& Casida の方法によって，1,5-ジヒドロキシナフタレンと イソシアン酸ジメチルから合成しだ)。 これらの化合物
は，それぞれ，関連する農薬の代謝物を同定するための コクロマトグラフィーに用いた。

\section{3. 供試生物}

次の 4 種の水棲生物を実験に供した.

グッピー(Lebistes reticulatus Peters), 体重約 $200 \mathrm{mg}$ の雌個体を 1 試験処理区当たり 4 6 個体用いた。 red snail (Indoplanorbis exustus Deshays), 体重約 $200 \mathrm{mg}$ の個体を 1 試験処理区当たり 5 個体使用した。チカイエ 力幼虫 (Culex pipiens pallens molestus Foriskal), 4 令 の個体（約 $2 \mathrm{mg} /$ 頭）を約 500 頭用いた.

ミジンュ (Daphnia pulex deGeer), 雌成熟個体（約 $0.7 \mathrm{mg} /$ 頭）約 1,500 頭使用した.

な㧍，使用前に，グッピーと red snail は 24 時間, チカイエカ幼虫とミジンコは 3 時間，それぞれ農薬を含 まない $25^{\circ} \mathrm{C}$ の水に移して制致させた。

\section{4. 試験水の調製および実験条件}

水道水を活性炭で処理し， $25^{\circ} \mathrm{C}$ で一昼夜通気した水 を試験用水とした。この水に標識農薬のエチルセロソル ブ溶液を必要量添加し，十分攪拌したのちしばらく静置 した。農薬の種類によってはその一部が水の表面に遊離 してくる抢それがあるためサイフォンを用いて表層を残 し，下層の水を採取した。これを所定濃度 $(1 \mathrm{ppb})$ とな るようにさらに試験用水で希勫して試験水を調製した。 試験水の容量は，放飼する供試生物の重量の約 1 万倍に 設定して実験を行なった。

Fig. 1 亿魚を用いた場合の実験例を模式図で示した。 試験水槽は, $10 l$ 容の全ガラス製容器を用いた。水温 を $25^{\circ} \mathrm{C}$ に保持するため, 試験水槽をさらに大型の水槽 に入れ，外側の水槽を加温することによって，間接的に 試験水槽の水温を制御した。な打，試験水への通気は水 中の農薬の揮散が懸念されるので行なわなかった。

\section{5. 分析方法}

供試生物は経時的に採集し，水洗したのち，グッピー および red snail は紙タオルを用いて，また，チカイエ

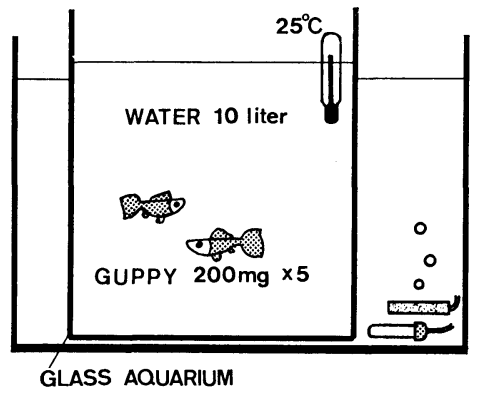

Fig. 1 Schematic drawing of aquarium tank. 
カ幼虫およびミジンコは吸引濾過して，それぞれ水を除 去し新鮮体重を称量した. 続いて, それぞれ, アセト二 トリルー水 $(7: 3)$ で磨砕抽出し, 吸引滤過し, 残椬を上 記の溶媒で洗浄した. 濾液を合わせ, クロロホルムを加 えて振とうし, クロロホルム層（クロロホルム分画）と 水層（水溶性分画）に液液分配し，それぞれの分画の一 部を採取して, 液体シンチレーションスペクトロメータ - (Nuclear Chicago 社製, Isocap 300 型) により放射 能を測定した。供試生物に蓄積された農薬およびその代 謝物の分離確認と定量を行なうために，さらに，クロロ

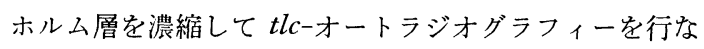
った. 抽出残椬 (不溶性分画) については, オートオキ シダイザー（日本無線医理学研究所製，ASC 111 型）に より, ${ }^{14} \mathrm{CO}_{2}$ として放射能を測定した。

試験水については, 実験開始 24 時間後の水を $100 \mathrm{ml}$ 採取し,クロロホルム $100 \mathrm{ml}$ を加えて振とうし，クロ ロホルム層と水層のそれぞれについて放射能を測定し た. また，一部のクロロホルム層は $t l c に$ 供した。

tlc に用いた展開溶媒は, 標識農薬の精製に用いたも のと同一のものを用いた.

\section{結果}

\section{1. 有機塩素殺虫剤の取り込み}

DDT とアルドリンの, グッピー, red snail, チカイ エカ幼虫およびミジンコによる取り込みを Fig. 2 に示 した.

DDT の場合, グッピーでは 24 時間後の ${ }^{14} \mathrm{C}$ 濃度は DDT 換算で $1,350 \mathrm{ppb}$ となり，tlc-オートラジオグラ フィーによりそのほとんどが DDT として存在している ことが確認された. 1 週間後の ${ }^{14} \mathrm{C}$ 濃度は $5,000 \mathrm{ppb}$ に 達した. red snail では 24 時間後の ${ }^{14} \mathrm{C}$ 濃度は $450 \mathrm{ppb}$ で，1週間後においてもわずかな増加に留まった。
グッピー, red snail, およびミジンコが水中の溶存酸 素を利用して呼吸するのに対して, チカイエカ幼虫は空 気呼吸する点で他の 3 種の水棲生物と生理的に大きく異 なっていると考えられるが，チカイエカ幼虫の 24 時間 後の ${ }^{14} \mathrm{C}$ 濃度は $3,400 \mathrm{ppb}$ で, 4 種の供試生物のなか で最も大きい值を示した。

ミジンコは，1時間後まではチカイエカ幼虫と同様の 急速な取り込みが認められたが, 実験開始の約 3 時間後 から死亡する個体が現われ，24 時間後にはほとんどの 個体が死亡した。

Table 1 に, 4 種供試生物のクロロホルム分画の $t l c-$ オートラジオグラフィーによる放射能の分布を示した. グッピー, red snail およびチカイエカ幼虫については 24 時間後, ミジンコについては 3 時間後の值を表示し た.

グッピーでは, 取りこまれた DDT の代謝がほとんど 進まなかった. これに対して, チカイエカ幼虫では DDT から DDEへの変換が容易に進行しており, また, 他の 3 種の生物と比べて多種類の代謝物のスポットが認めら れた. red snail は, 他の 3 種の生物が DDE への変換を 主とするのに対し, DDD への変換を主とする特徴があ り, $t l c$ の原点に残る極性の代謝物もやや多かった。 24 時間後の試験水は，いずれもほとんどの ${ }^{14} \mathrm{C}$ がクロロホ ルム分画に存在したが, 体内への取り込み量の多かった チカイエカ幼虫の試験水の ${ }^{14} \mathrm{C}$ 濃度が, 他と比較しても っとも減少していた (Table 2).

アルドリンの場合, 取り込み量の最も多い供試生物は DDT の場合と同様にチカイエカ幼虫で, 以下, グッピ ー>ミジンコ>red snail の順であった. ディルドリンヘ の変換速度では, 生物種間に大きな相違が認められ，グ ッピーでは, 時間の経過とともに生物体内の ${ }^{14} \mathrm{C}$ の大部 分がディルドリンに変換されるのに対し，ミジンコでは

Table 1 Per cent distribution of DDT and its metabolites in chloroform fraction of aquatic organisms.

\begin{tabular}{|c|c|c|c|c|c|}
\hline & $R f^{*}$ & Fish** & Snail** & $\begin{array}{c}\text { Mosquito } \\
\text { larva** }\end{array}$ & Daphnia*** \\
\hline DDE & 0.79 & 1.3 & trace & 54.2 & 0.9 \\
\hline $\mathrm{I} * * * *$ & 0.65 & & & 0.7 & \\
\hline DD'T & 0.55 & 98.2 & 94.6 & 39.4 & 98.5 \\
\hline DDD & 0.36 & 0.3 & 3.3 & 1.9 & 0.4 \\
\hline II & 0.10 & & & 2.6 & \\
\hline Origin & 0.00 & 0.2 & 2.1 & 1.2 & 0.2 \\
\hline
\end{tabular}

* Silica gel GF-254, $n$-hexane: ethyl ether, 100: 2 by volume.

** 1 day after treatment.

*** 3 hours after treatment.

**** Roman numerals indicate compounds whose chemical structures are unknown. 


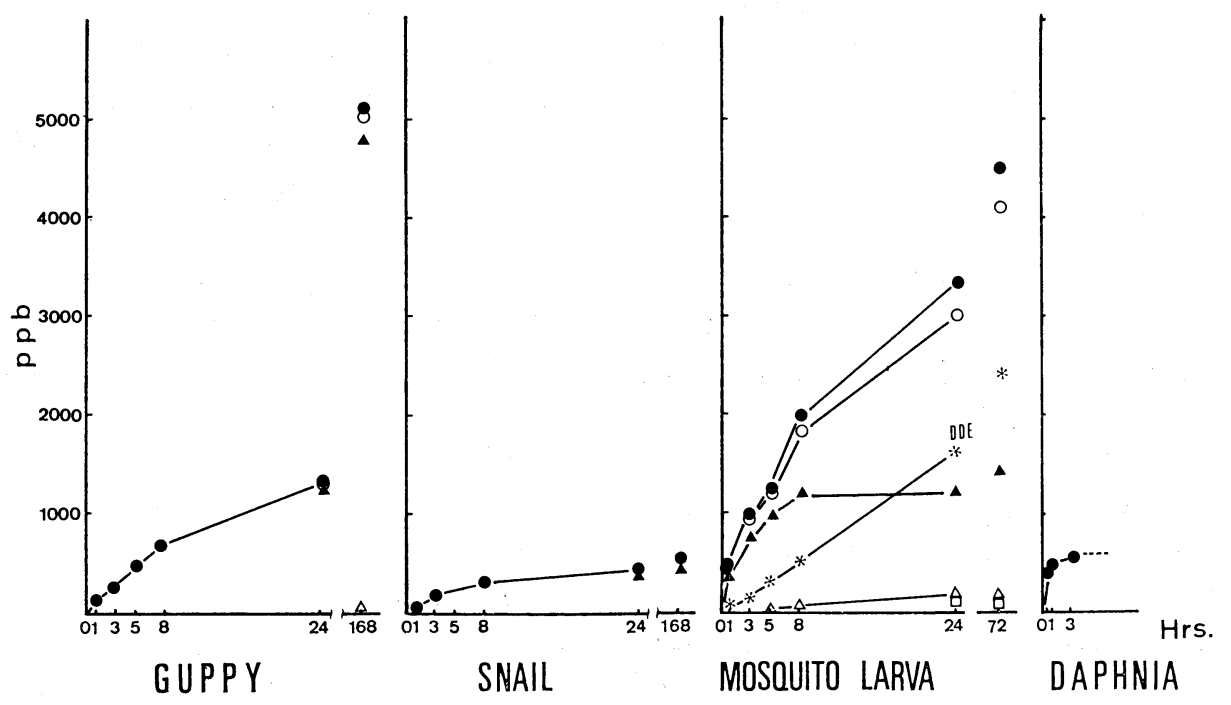

D D $\mathrm{T}$

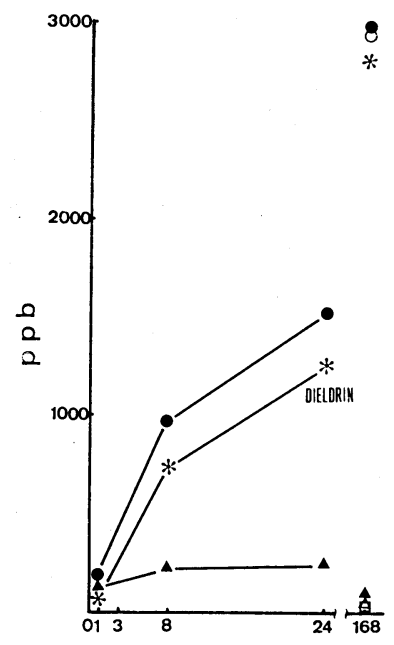

GUPPY

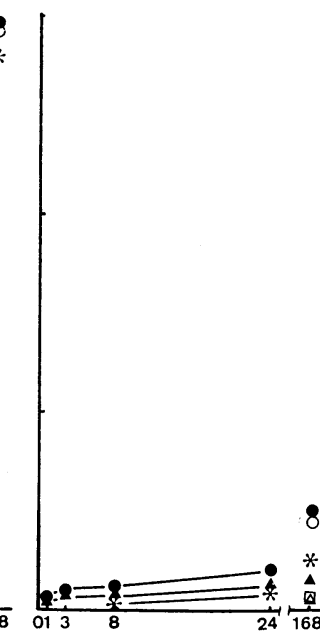

SNAIL

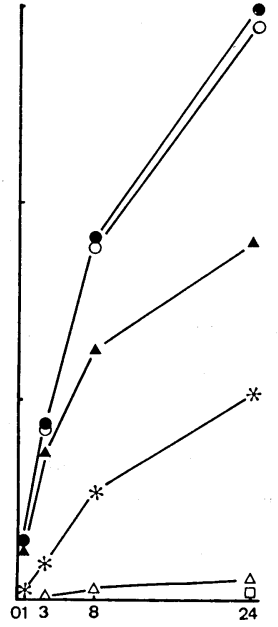

MOSQUITO LARVA

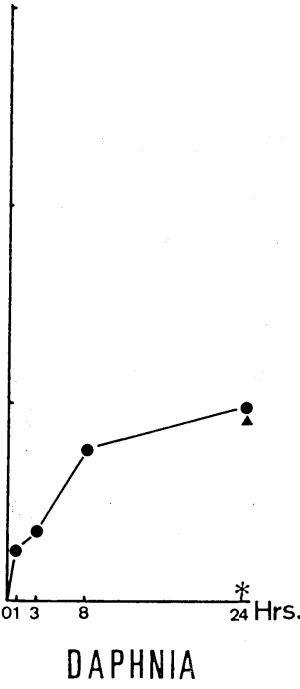

APHNIA

\section{ALDRIN}

Fig. 2 Uptake and fate of organochlorine insecticides by aquatic organisms.

๑: total ${ }^{14} \mathrm{C}, O:{ }^{14} \mathrm{C}$ in chloroform fraction, $\triangle:{ }^{14} \mathrm{C}$ in aqueous fraction,

$\square:{ }^{14} \mathrm{C}$ in residue fraction, $\boldsymbol{\Delta}$ : insecticide, $*$ : metabolite.

ディルドリンへの変成はわずかであり，ほとんど親化合 物のアルドリンの形態で存在していた.

\section{2. 有機リン殺虫剤の取り込み}

プロチオホスとイソチオエートについての結果を,

Fig. 3 に示した.
プロチオホスの場合, 取り込み量の最も多い供試生物 はミジンコで, ${ }^{14} \mathrm{C}$ の大部分は親化合物で占められてい るのに対し, 他の 3 種の生物の ${ }^{14} \mathrm{C}$ 濃度は相対的に低く ${ }^{14} \mathrm{C}$ 全体に占める親化合物の比率は 24 時間後で $2 / 3 \sim$ 1/4 であった. グッピーでは親化合物から水溶性物質へ 


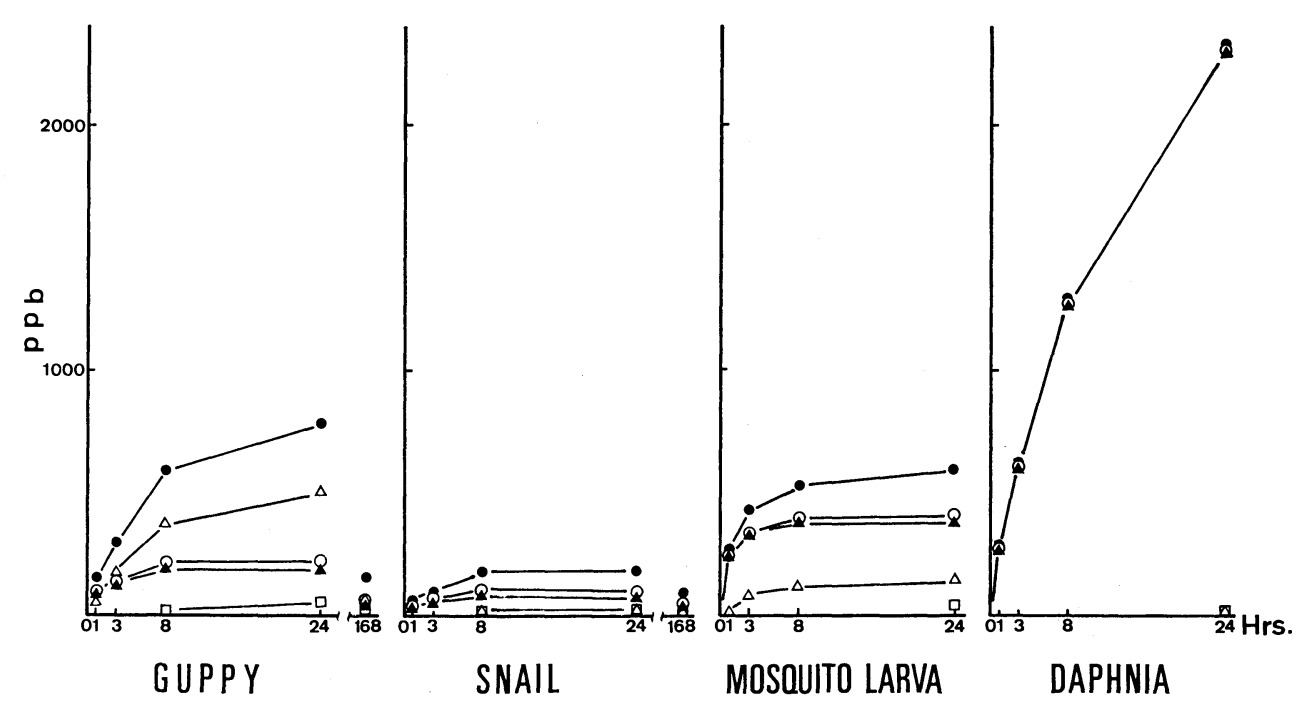

\section{PROTHIOPHOS}

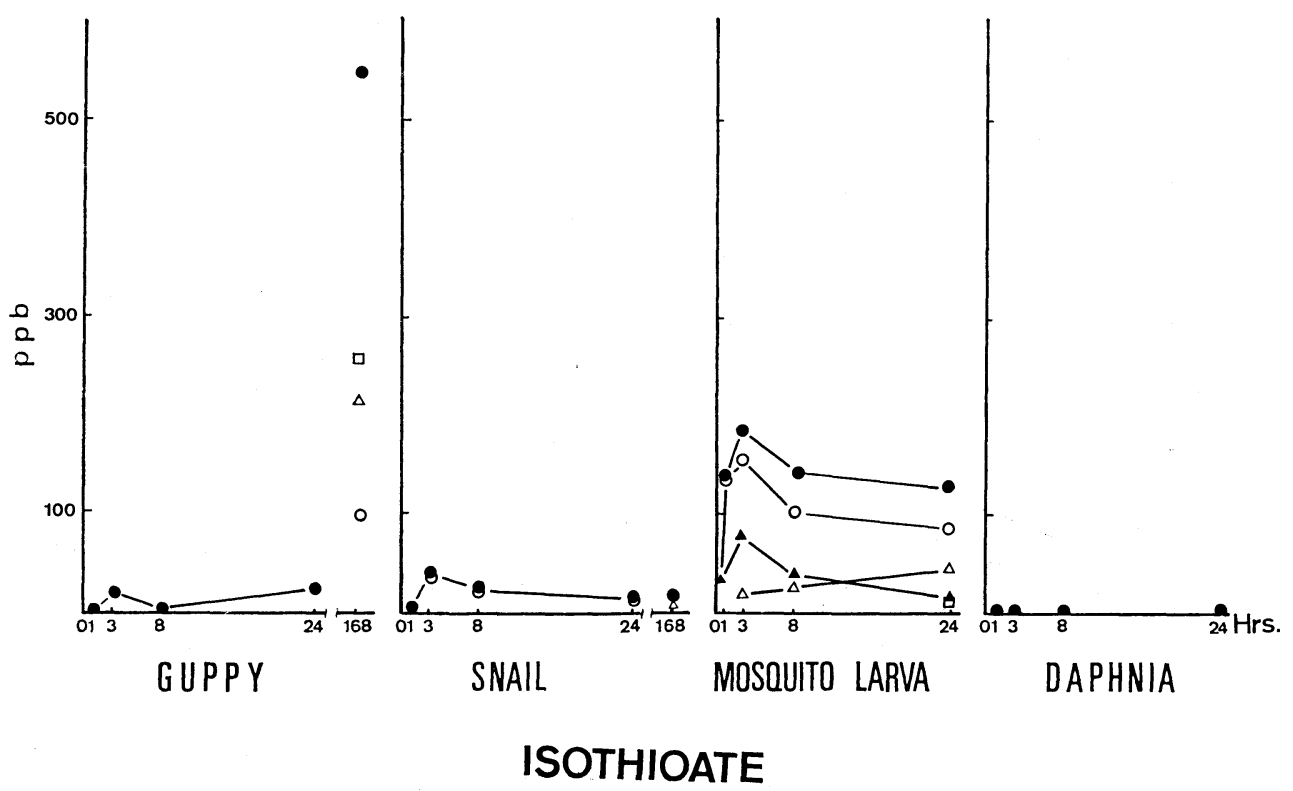

Fig. 3 Uptake and fate of organophosphorus insecticides by aquatic organisms.

- total ${ }^{14} \mathrm{C}, O:{ }^{14} \mathrm{C}$ in chloroform fraction, $\Delta:{ }^{14} \mathrm{C}$ in aqueous fraction,

$\square$ : ${ }^{14} \mathrm{C}$ in residue fraction, $\boldsymbol{\Delta}$ : insecticide.

の代謝が顕著で， 3 時間後以降で水溶性分画の放射能が クロロホルム分画のそれを上回った．プロチオホスは水 から容易に生物体内に取り込まれるが，代謝能力のそし いミジンコを除けば，比較的速く代謝されるために，親 化合物の形態での残存は低い值を示した。
イソチオェートの場合，放射能の取り込みはプロチオ ホスと比べてかなり小さく, チカイエカ幼虫の場合実験 の初期にやや取り込みが認められたものの， ${ }^{14} \mathrm{C}$ 濃度で $200 \mathrm{ppb}$ を超えることはなかった。 また，いずれの供試 生物からも親化合物は検出されなかった. Table 2 に示 


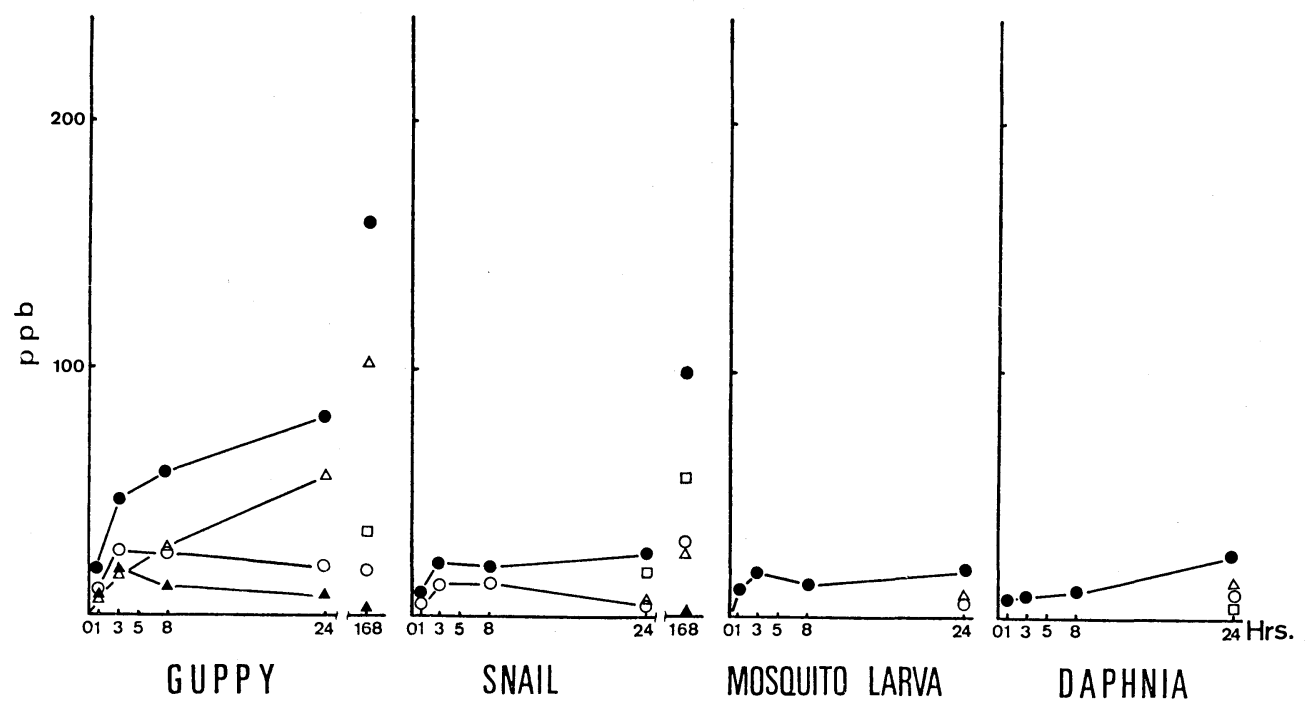

CARBARYL
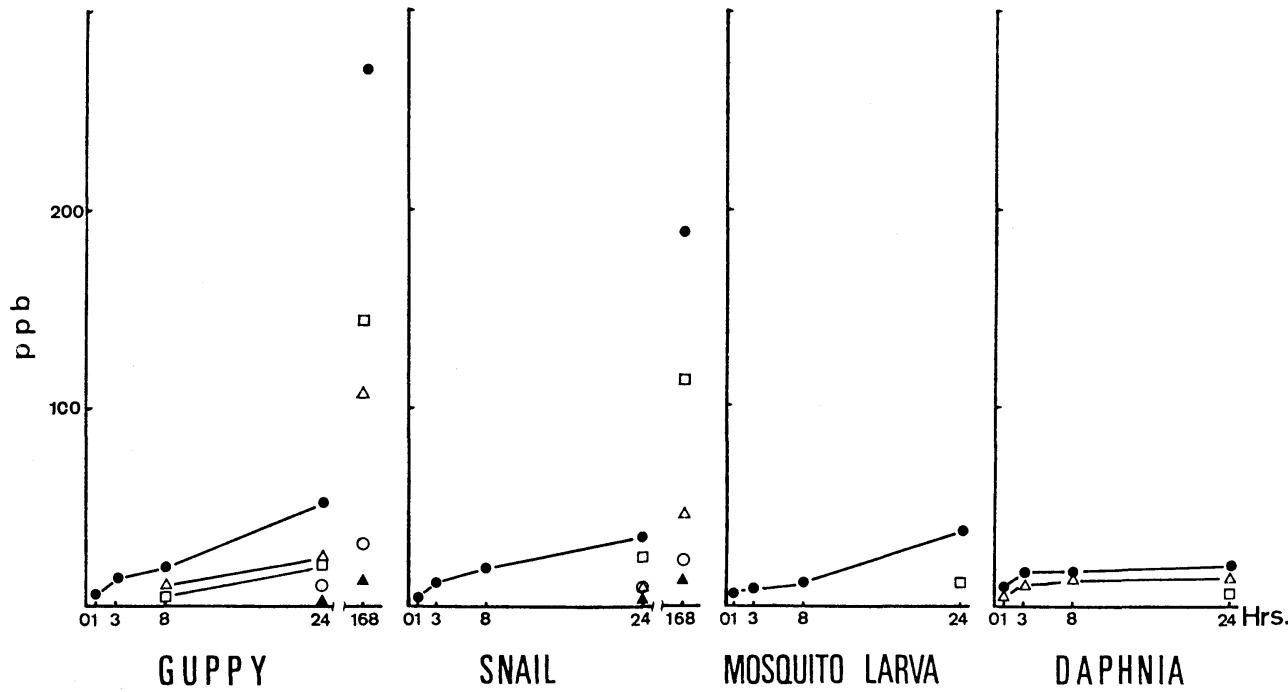

\section{M C}

Fig. 4 Uptake and fate of carbamate insecticides by aquatic organisms. 0: total ${ }^{14} \mathrm{C}, \mathrm{O}:{ }^{14} \mathrm{C}$ in chloroform fraction, $\triangle:{ }^{14} \mathrm{C}$ in aqueous fraction, $\square:{ }^{14} \mathrm{C}$ in residue fraction, $\boldsymbol{\Delta}$ : insecticide.

したイソチオエートにおける 24 時間後の試験水の放射 能分布はいずれの供試生物区についても， ${ }^{14} \mathrm{C}$ 全体の $50 \%$ 前後を水溶性分画が占めており，この農薬の水中 での易分解性を暗示させた。
3. カーバメート殺虫剤の取り込み

カルバリルと XMC についての結果を, Fig. 4 に示 した。

カルバリルの場合, 24 時間後の供試生物中の ${ }^{14} \mathrm{C}$ 濃 度はいずれも親化合物換算で $100 \mathrm{ppb}$ 以下であった．生 
Table 2 Concentration of radioactivity in chloroform fraction and in aqueous fraction from water kept aquatic organisms 1 day after treatment.

\begin{tabular}{|c|c|c|c|c|c|c|c|c|}
\hline \multirow{3}{*}{ Pesticide } & \multicolumn{8}{|c|}{ Concentration, equivalent $\mathrm{ppb}$} \\
\hline & \multicolumn{2}{|c|}{ Fish } & \multicolumn{2}{|c|}{ Snail } & \multicolumn{2}{|c|}{ Mosquito larva } & \multicolumn{2}{|c|}{ Daphnia } \\
\hline & $\mathrm{CHCl}_{3}$ & $\mathrm{H}_{2} \mathrm{O}$ & $\mathrm{CHCl}_{3}$ & $\mathrm{H}_{2} \mathrm{O}$ & $\mathrm{CHCl}_{3}$ & $\mathrm{H}_{2} \mathrm{O}$ & $\mathrm{CHCl}_{3}$ & $\mathrm{H}_{2} \mathrm{O}$ \\
\hline DDT & 0.90 & 0 & 0.95 & 0 & 0.69 & 0.02 & 0.98 & 0 \\
\hline Aldrin & 0.70 & 0 & 0.95 & 0 & 0.68 & 0.01 & 0.71 & 0 \\
\hline Prothiophos & 0.76 & 0.21 & 0.63 & 0.23 & 0.72 & 0.21 & 0.37 & 0.18 \\
\hline Isothioate & 0.44 & 0.51 & 0.53 & 0.45 & 0.43 & 0.55 & 0.48 & 0.46 \\
\hline Carbaryl & 0.66 & 0.11 & 0.61 & 0.16 & 0.60 & 0.11 & 0.82 & 0.05 \\
\hline $\mathrm{XMC}$ & 0.93 & 0.01 & 0.95 & 0.03 & 0.82 & 0.04 & 0.91 & 0.05 \\
\hline
\end{tabular}

Table 3 Per cent distribution of carbaryl and its metabolites in chloroform fraction of aquatic organisms and water kept them for 7 days.

\begin{tabular}{|c|c|c|c|c|c|c|c|c|c|}
\hline & \multirow{2}{*}{$R f^{*}$} & \multicolumn{3}{|c|}{ Guppy } & \multicolumn{3}{|c|}{ Snail } & \multirow{2}{*}{$\begin{array}{l}\text { Mosquito } \\
\text { larva** }\end{array}$} & \multirow{2}{*}{ Daphnia** } \\
\hline & & 1 day** & 7 days & Water & 1 day & 7 days & Water & & \\
\hline $\mathrm{I} * * *$ & 0.98 & & 14.0 & 5.0 & 55.4 & 79.0 & 4.1 & 95.6 & 97.8 \\
\hline 1-naphthol & 0.90 & & & 19.5 & & & 2.3 & & \\
\hline II & 0.72 & & & & & & & & 0.1 \\
\hline Carbaryl & 0.61 & 14.0 & 2.0 & 29.0 & 24.6 & 12.0 & 88.0 & 0.9 & 0.7 \\
\hline $\begin{array}{r}\text { 5-hydroxy } \\
\text { carbaryl }\end{array}$ & 0.38 & & & 27.0 & & & 2.2 & & 1.4 \\
\hline Origin & 0.00 & 86.0 & 84.0 & 19.5 & 20.0 & 9.0 & 3.4 & 3.5 & \\
\hline
\end{tabular}

* Silica gel GF-254, ethyl ether : $n$-hexane, $4: 1$ by volume.

** 1 day after treatment.

*** Roman numerals indicate compounds whose chemical structures are unknown.

物に取り込まれた放射能の分布をみると，水溶性分画ま たは不溶性分画に含まれる割合が大きく，親化合物であ るカルバリルの形態での生物体内への残存量はわずかで

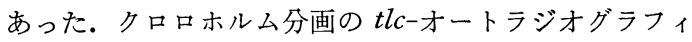
一による放射能の分布を Table 3 に示した。

グッピーでは ${ }^{14} \mathrm{C}$ の大部分が極性の代謝物として原点 に残るのに対し, 他の 3 種の水棲生物では ${ }^{14} \mathrm{C}$ の大部分 が $R f$ 值 1.0 付辺に分布し, 生物種による代謝の相違 が認められた。

なお，7 日後のグッピーと red snail の試験水から， 1ーナフトールと 5-ヒドロキシカルバリルが検出された がこれらの化合物は供試生物体から検出されなかったの で, 水中の微生物に由来する代謝物ではないかと推定さ れる。

$\mathrm{XMC}$ の場合も, カルバリルの場合とほぼ同様に ${ }^{14} \mathrm{C}$ の取り込み量は経時的にある程度増加するが, 代謝が早 いので親化合物である XMC の形態での残留は少なかっ た。

同一条件で行なわれたカルバリルと XMC のモデルエ
コシステム ${ }^{3,4)}$ における生物濃縮係数 (Ecological magnification value $\left.{ }^{7)}=\frac{\text { 供試生物体中の親化合物の濃度 }}{\text { 試験水中の親化合物の濃度 }}\right)$ は, グッピーおよび red snail のいずれにおいても XMC の ほうが大きかったが，本実験のように単純化した系での 呼吸および体表からの浸透による取り込みでは，カルバ リル，XMC ともに生物濃縮性の低い農薬であるという 結果を示した。

なお，Table 2 に示した XMC の 24 時間後の試験水 の放射能分布は, カルバリルと比べて水溶性分画に含ま れる放射能の割合が低かった。

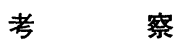

\section{1. 試 験方法}

化学物質の水棲生物に対する影響を把握するための実 験には，大きく分けて止水式と定濃度流水式（連続流水 式)の試験方法があるが, 本報告のように放射性同位元素 を用いた実験では，薬量の確保と廃液の処理が困難であ るため, 止水式を採用した。 この場合, 試験水量に対して 
供試生物の総量が多いと, 生物体に取り込まれやすい性 質を有する農薬の試験では, 試験水中の農薬が急速に減 少する結果, 当初の試験設定濃度との間に著しい相違が 生ずる. 農林水産省や日本工業規格の魚類に対する毒性 試験法 ${ }^{8,9)}$ では, 主として溶存酸素量を考慮して, 試験水 量 $1 l$ に対して供試魚の重量 $1 \mathrm{~g}$ の比率 $(1,000: 1)$ を 基準としているが, 取り込み量の大きい農薬について試 験する場合は, 試験水を頻繁に交換する等の工夫が必要 であろう。

試験水中の農薬濃度は, 金沢・富沢 ${ }^{10)}$ の報告にみられ るように, 定濃度流水式においても試験開始後 $2 \sim 3$ 日 は低下することが観察されており，濃度の維持は，この 種の試験を行なう場合の大きな課題となっている.

本報告では, 試験水量と供試生物の総重量の比率を, 10,000:1 に一定して実験を行ない, 試験開始後 24 時 間では, 試験設定濃度の維持に比較的満足すべき結果が 得られたが, 数日間にわたる試験ではカルバリルで示さ れたように, 水中微生物の繁殖によると考えられる影響 等が加わってくる可能性があるので，止水式による長期 の試験には限界があると判断された。 また，イソチオエ 一トのように，とくに水中で分解されやすい農薬につい ては, 試験設定濃度の維持は困難であろう。

\section{2. モデルエコシステムとの比較}

前報 ${ }^{3)}$ に示したように, DDT のモデルエコシステムに よる実験結果では，グッピーおよび red snail (生物濃縮 係数は，それぞれ，13,047 および 6,241）にDDT が 高濃度に蓄積された.DDT の本実験における結果では, グッピーは DDT を高濃度に蓄積したが, red snail につ いては 7 日後の生物体内の DDT 濃度がグッピーの 10 分の 1 以下であり，グッピーが食物連鎖を経由せずに呼 吸および体表からの浸透のみによっても生物濃縮が高濃 度にまで進行しうるのに対し, red snail については, 呼 吸および体表からの浸透のみでは高濃度に達しないこと が確認された。このことからモデルエコシステムにお ける red snail への DDT の高濃度の蓄積は主として食 物連鎖（藻類の摂食）によって進行したものであること が暗示された。

また，本実験のカルバリルと XMC の結果では，いず れの供試生物についても親化合物はほとえど蓄積されず Kanazawa によるこれらの農薬のモッゴに対する取り込 みの報告 ${ }^{11)}$ と同様の結果を得た. しかしながら，モデル エコシステムを用いた XMC についての実験4ではグッ ピーと red snail の生物濃縮係数（それぞれ 1,477 と 318）として比較的高い数值が得られており, 一方, 本 実験の結果から呼吸および体表からの浸透による XMC
の濃縮は否定されたので, グッピーと red snail の場合 には食物連鎖により XMC が両生物に濃縮されたと考え られる。

\section{3. 農薬および生物の種類の相違による取り込みの差 異}

本実験の結果から, 農薬の種類によって, 水棲生物に よる取り込みや蓄積には大きな相違があり, 有機りン殺 虫剤およびカーバメート殺虫剤は有機塩素殺虫郕と比べ て蓄積性が小さく，また，有機リン殺虫剤でも水に対す る溶解度（プロチオホス $1.7 \mathrm{ppm，イソチオエート90}$ ppm）の違いによって取り込みにかなりの差異を生ずる ことが明らかである。

Metcalf \& Sanborn ${ }^{12)}$ は数十種に及ぶ農薬についての モデルエコシステムを用いた研究から魚類による親化合 物の生物濃縮係数と農薬の水に対する溶解度の間に, か なり高い負の相関性 $(\boldsymbol{r}=-0.76)$ があることを報告して いるが，本実験で用いた 6 種類の農薬についても，グッ ピーにおける生物濃縮性は同様の傾向を示している.

また, 同一農薬についても, 水棲生物の種の違いによ り, 取り込み, 蓄積および代謝にかなりの相違が認めら れた. 西内・吉田 ${ }^{13)}$ は, red snail を含む淡水産巻貝での 108 種類の農薬に対する感受性の研究において, 巻貝 (red snail) は魚（コイ）と比較して薬郕感受性が低く両 者の感受性の間には高い相関性がみられないと報告して いるが，本実験の結果においても，巻貝 (red snail) は 取り込み量や蓄積量が魚（グッピー）よりも少なく両者 の取り込み量や蓄積量の間の相関性は低いようである.

チカイエカ幼虫は, 他の 3 種の供試生物と比べて農薬 の取り込みが顕著であったが，これは小動物では体表か らの浸透による取り込みが非常に大きな因子となってい ることを示唆している. ミジンコや力幼虫のような水棲 小動物においては, 農薬の種類によっては短時間に急速 に取り込まれる可能性が高く，これが食物連鎖によって 魚類への蓄積につながるおそれも䀣念されるので, 魚類 や貝類のみならず, 水棲小動物における農薬の取り込み や蓄積に関する知見を把握集積することは, 農薬の水質 環境への影響を明らかにするためにも重要な課題である と考えられる。

\section{要 約}

1) ${ }^{14} \mathrm{C}-\mathrm{DDT}$, アルドリン，プロチオホス，イソチオ エート, カルバリル, XMC の $1 \mathrm{ppb}$ 水溶液を調製し, グッピー, red snail, チカイエカ幼虫, ミジンコによる これらの農薬の取り込みを比較した。

2） DDT の場合，グッピーと red snail とでは取り込 
み量にかなりの相違が認められた。また，グッピーでは 取り込まれた放射能の大部分が DDT のままで存在した が, red snail では DDD に，チカイエカ幼虫ではDDE に変換していた.

3）アルドリンでは ${ }^{14} \mathrm{C}$ の取り込み量はチカイエカ幼 虫>グッピー>ミジンコ>red snail の順であった。 ま た,ディルドリンへの変換は生物種により相違が認めら れ，グッピーでは時間の経過とともに大部分の ${ }^{14} \mathrm{C}$ がデ ィルドリンに変換されるのに対し, ミジンコでは ${ }^{14} \mathrm{C}$ は 漞化合物の形態で検出された.

4）プロチオホスはミジンコを除いて生物体内で水溶 性物質への代謝が顕著であり, 水溶液からの取り込みは 多くても親化合物の形態での残存量は小さかった.

5）イソチオエートの取りこみはプロチオホスよりも さらに小さく，また，いずれの生物からも親化合物は検 出されなかった。

6) カルバリルとXMC の場合, 取り込まれた放射能 の大部分は水溶性または不溶性分画に分布し, 親化合物 としての存在量はわずかであった。

7）生物による水からの農薬の取り込み量は生物種や 化合物によりかなりの相違があることが認められた。 た，食物連鎖を通しての取り込みと水からの直接の取り 込みとの間には必ずしも相関はなく, 生物種と化合物に より食物連鎖による取り込みの寄与の程度に差が認めら れた。
おわりに, メチル- ${ }^{14} C$-標識ーイソチオエートを提供い ただいた日本農薬株式会社，および，チカイエカを提供 いただいた日本特殊農薬製造株式会社に謝意を表する.

\section{引用文献}

1) R. L. Metcalf, G. K. Sangha \& I. P. Kapoor: Environ. Sci. Tech. 5, 709 (1971)

2) H. Kazano, M. Asakawa \& C. Tomizawa: Appl. Entomol. Zool. 10, 108 (1975)

3) S. Tsuge, H. Kazano \& C. Tomizawa: $J$. Pesticide Sci. 1, 307 (1976)

4) H. Kazano, M. Asakawa, C. Tomizawa \& S. Tsuge: Appl. Entomol. Zool. 11, 263 (1976)

5) A. Kudamatsu: Jpn. Pestic. Inf. No. 26, 14 (1976)

6) H. W. Dorough \& J. E. Casida: J. Agric. Food Chem. 12, 294 (1964)

7) R. L. Metcalf, I. P. Kapoor, P. Y. Lu, C. K. Schuth \& P. Sherman: Environ. Health Pers. 4, 35 (1973)

8）農薬検査所報告 9, 45 (1969)

9) JIS K 0102 (1974)

10）金沢 純・富沢長次郎：日本農薬学会第 2 回大会 講演要旨集, p. 236, 1977

11) J. Kanazawa: Bull. Environ. Contam. Toxicol. 14, 346 (1975)

12) R. L. Metcalf \& J. R. Sanborn: Ill. Nat. Hist. Surv. 31, 379 (1975)

13）西内康浩·吉田孝二：農薬検査所報告 12, 86 (1972) 